\title{
Effects of Hydrostatic Pressure on the Nitrogen Cycle of Sediment
}

\author{
Bei-bei Chai ${ }^{1,2 *}$, Ting-lin Huang ${ }^{3,4}$, Xiao-guang Zhao², Yajiao Li $^{2}$ \\ ${ }^{1}$ School of Architecture and Civil Engineering, Xi' an University of Science \& Technology, \\ Xi'an 710054, P.R. China \\ ${ }^{2}$ Geological Resources and Geological Engineering Postdoctoral Research Station, \\ Xi'an University of Science \& Technology, Xi'an 710054, P.R. China \\ ${ }^{3}$ School of Environmental and Municipal Engineering, Xi' an University of Architecture \& Technology, \\ Xi'an 710055, P.R. China \\ ${ }^{4}$ Key Laboratory of Northwest Water Resources, Environment and Ecology, \\ MOE, Xi'an 710055, P.R. China
}

Received: 19 May 2016

Accepted: 5 July 2016

\begin{abstract}
We carried out a simulation experiment in a laboratory in order to study the effects of hydrostatic pressure from 0.1 MPa to 1.0 MPa on nitrogen cycles at the water-sediment interface of a freshwater reservoir. The results show that high hydrostatic pressure facilitates the release of nitrogen at the interface and ammonification, but has little influence on denitrification. And high hydrostatic pressure will also significantly increase the activity of dehydrogenases and proteases in the sediment, and has little influence on ureases and nitrate reductase activity. The pressure caused a large accumulation of such pollutants as ammoniacal nitrogen and nitrate nitrogen at the interface, seriously worsening the overlying water quality. As PLFA and PCR-DGGE analysis results show, different hydrostatic pressures will lead to remarkable differences in the microbial community's structure and heredity. Within the range $0.1 \mathrm{MPa}$ to $1.0 \mathrm{MPa}$, the microbial community structure is more diverse under high hydrostatic pressure than under normal pressure.
\end{abstract}

Keywords: hydrostatic pressure, reservoir, nitrogen cycles, microbial community diversity, water-sediment interface

\section{Introduction}

Eutrophication is currently one of the most serious environmental problems that impair water quality of urban water bodies [1-2]. Bottom sediment is considered to be a sink or a source of nitrogen $(\mathrm{N})$ and phosphorus (P) from overlying water, and therefore it plays an

*e-mail: chaibeibei@xust.edu.cn important role in the eutrophication process not only by removing nutrients but also due to their recirculation [35]. Nitrogen and phosphorus contents and their forms in sediments depend on the allochthonous point and diffuse sources, the geological structure of a catchment (type of rock and its mineral composition), and soils, as well as hydrometeorological conditions [6-8]. The autochthonous sources are also of great importance, especially in the case of nitrogen-organic matter (phytoplankton, macrophytes) [8]. Nitrogen pollution of drinking-water reservoirs has 
become an increasingly serious problem worldwide, especially in arid and semiarid regions of China [9-11]. Reservoir water is the primary source of drinking water for many citizens, and nitrogen pollution may cause a significant deterioration in water quality and therefore threaten the safety of the drinking-water supply [9]. Excessive discharges of $\mathrm{N}$ to aquatic ecosystems have led to increasing frequencies and geographic expansion of harmful algal blooms, hypoxia, habitat degradation, and decline of biodiversity [12]. Nitrogen is an essential element for algae growth and one of the nutrients triggering eutrophication. In all the forms of nitrogen, algae commonly absorb only inorganic nitrogen, mainly in the form of ammonium [13-14]. The primary factors influencing the rate of denitrification, which was the vital part of nitrogen cycle, included microorganisms, dissolved oxygen, temperature, and nitrate in sediments [15].

In freshwater ecosystems, microbial communities harbored in the sediment play a pivotal role in biogeochemical cycling due to their involvement in the transformation of nitrogen $(\mathrm{N})$ [16], and the sedimentassociated microbial community is particularly vital for the maintenance of ecosystem function and health in aquatic environments [17]. The sediment microbial community has drawn great attention from microbial ecologists [18-21]. Moreover, the sediment host distinct microbial communities and their populations may strongly be affected by the nutritional status of water quality due to the variations of hydrological regime and other physical and chemical variables, including hydrostatic pressure [22-25].

Pressure is a very important environmental parameter for microbial life [26]. Some scholars have reported the effects of high hydrostatic pressure (HHP) on enzymes [27], gene expressions [28-29], and microbial alterations [30-31]. The influence of high hydrostatic pressure on iron reduction bacterium was conducted by Picard and Wu [32-33]. But all this research only focused on deep sea environments, where hydrostatic pressures were usually larger than $10 \mathrm{MPa}$. However, for most drinking water reservoirs their depth usually is between several meters and 100 meters $(0.1-1 \mathrm{MPa}$; depths of more than $100 \mathrm{~m}$ are rarely seen). Thus, the microbial community structure and function response to hydrostatic pressure, ranging from $0.1 \mathrm{MPa}$ to $1 \mathrm{MPa}$, is not clear. As a consequence, with increasing pressure the lipid bilayer loses fluidity and rapidly becomes impermeable to water and other molecules, and protein lipid interactions essential to the optimal function of the membrane are weakened [34]. Low temperature and high hydrostatic pressure have related and synergistic effects on biological membranes [34], reducing their fluidity by increasing the packing of fatty acyl chains. Our recent studies provided preliminary knowledge of hydrostatic pressure effects on the microbial community in three drinking water reservoir sediments [35]. In this research, HHP's effect on nitrogen cycles at the watersediment interface of source water reservoir was studied by a comparison experiment between different hydrostatic pressures.

\section{Materials and Methods}

\section{Collection of Sediment and Overlying Water Samples}

Undisturbed surface sediment samples were collected with a stainless steel core sampler (100 cm length and $15 \mathrm{~cm}$ diameter) from Heihe Jinpen Reservoir in Xi'an,
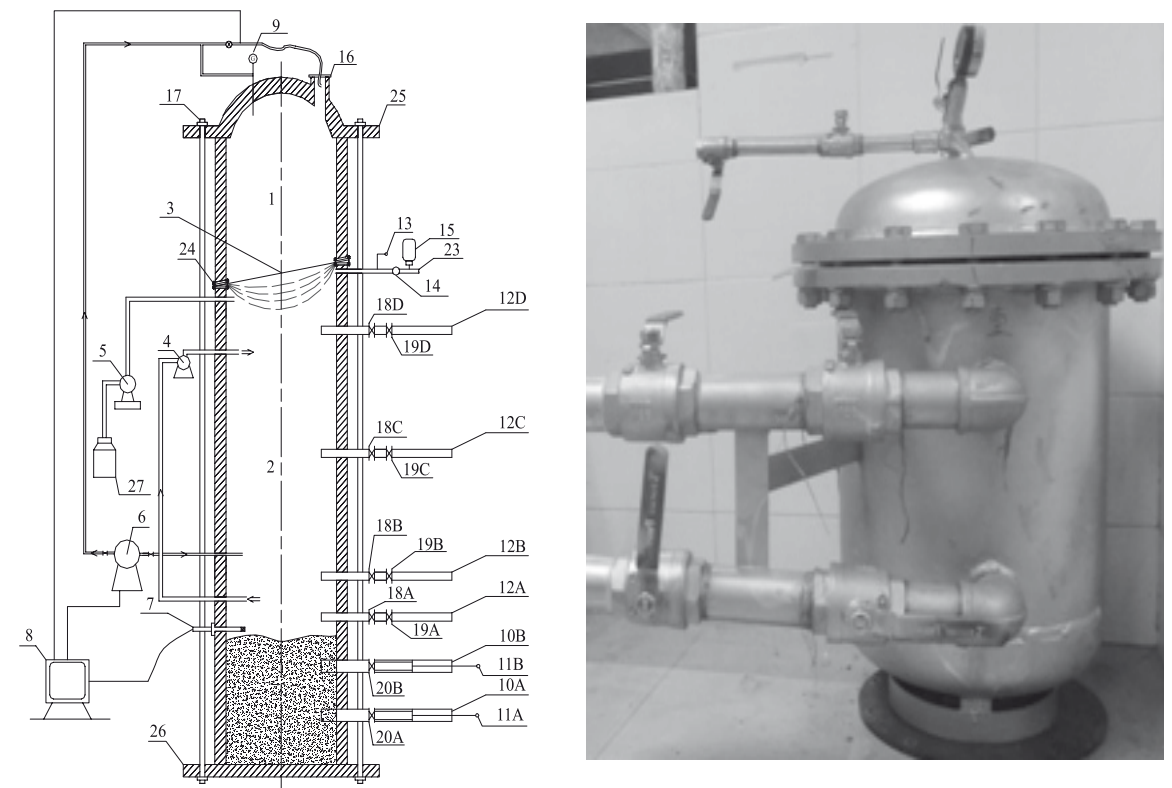

Fig. 1. structure and installation diagrams of high-pressure simulation reactor and its physical device.

1) Gas chamber, 2) reaction chamber, 3) elastic diaphragm, 4) hydraulic stirring device, 5) dosing pump, 6) air compressor, 7) online monitoring probe, 8) control device, 9) barometer, 10) sediment sampler, 11) spiral high-pressure piston propeller, 12) water sampler, 13) exhaust valve, 14) gas flowmeter, 15) gas collector, 16) pressure hole, 17) connecting rod and bolt, 18) pressure relief valve, 19-20) control valve, 23) exhaust pipe, 24) connecting flange, 25) upper cover body, 26) bottom cover body, and 27) medicine storage tank. 
China. Overlying water $5 \mathrm{~cm}$ above the water-sediment interface was also collected from the same reservoir. Any debris and fragments of macrofauna were manually removed.

\section{Simulation Experiment Design}

There were three reactor simulators in the simulation experiment, which were under normal pressure, $0.4 \mathrm{MPa}$ pressure (equivalent to that of $40 \mathrm{~m}$ under water) and $0.9 \mathrm{MPa}$ (equivalent to that of $90 \mathrm{~m}$ under water).

The simulator with the high-pressure interface adopted in the simulation experiment was divided into an air chamber and reaction chamber separated by a resilient diaphragm, through which the pressure caused by inflating the air chamber could be transmitted to the lower sedimentwater interface so as to realize the simulation of high hydrostatic pressure at the interface. Fig. 1 demonstrated the structure and installation diagrams. The effective volume of the simulator was $50 \mathrm{~L}$, and $10 \mathrm{~L}$ sediment was placed in the bottom with $40 \mathrm{~L}$ overlying water injected with a siphon to avoid disturbance to the interface.

The temperature during the simulation process was controlled with $10^{\circ} \mathrm{C} \pm 1^{\circ} \mathrm{C}$ (equivalent to that at the water surface of a deep-water reservoir) with the help of a freezer. During the simulation experiment, the simulators were sealed and the concentration of dissolved oxygen (DO) was achieved by normal oxygen consumption at the interface to an anaerobic state.

\section{Methods}

Overlying water samples were collected $5 \mathrm{~cm}$ above the water-sediment interface and finally obtained through microporous filtering film $(0.45 \mu \mathrm{m}$ pore size $)$. Ammonia nitrogen $\left(\mathrm{NH}_{4}^{+}\right)$, nitrite nitrogen $\left(\mathrm{NO}_{2}^{-}\right)$, nitrate $\left(\mathrm{NO}_{3}^{-}\right)$, and total nitrogen (TN) were estimated according to Standard Methods for the Examination of Water and Wastewater [36]. Sediment total nitrogen was measured according to the zinc cadmium reduction method after being digested by alkaline potassium persulfate. Sediment dehydrogenase, protease, urease, and nitrate reductase activities were determined according to the method described by Guan Songyin [37] with little modification. The same procedure was followed for the control assays, with the exception that the substrate and sediment were added. Sediment enzyme activities were examined with replicates $(n=3)$.

\section{Lipid Extraction and Gas Chromatography Mass Spectrometry (GC-MS) Analysis}

Sediment samples (4 g) were extracted overnight using the modified method described by Bligh and Dyer [38]. Phospholipids were converted to fatty acid methyl esters (FAME) by heating with $3 \mathrm{~mL}$ of $0.5 \%$ methanolic hydrochloric acid $(\mathrm{HCl})$. Hexane/chloroform $(4: 1 \mathrm{v} / \mathrm{v})$ was used to extract FAME and the solution was evaporated under a stream of nitrogen. Internal standards of C 19:0 methyl ester were employed and the FAMEs were dissolved in hexane for chromatographic analysis. FAMEs were stored in $\mathrm{GC}$ vials at $-20^{\circ} \mathrm{C}$ until GC-MS analysis. Samples $(1 \mu \mathrm{L})$ were injected by an AOC-20I auto sampler of a QP2010 plus GC/MS (GCMS-QP2010 plus, Shimadzu, Japan) The column flow was $1.05 \mathrm{~mL} / \mathrm{min}$. Full scan-selected ion monitoring mode (scan-SIM) was used for the quantification of FAMEs. Helium was the carrier gas at a constant flow of $1.0 \mathrm{~mL} / \mathrm{min}$. The ion source temperature was maintained at $200^{\circ} \mathrm{C}$. Temperature program for FAME analysis was: injector temperature $260^{\circ} \mathrm{C}$; temperature program, $50^{\circ} \mathrm{C}$ (2 $\mathrm{min}), 50-200^{\circ} \mathrm{C}\left(3^{\circ} \mathrm{C} / \mathrm{min}\right), 200-240^{\circ} \mathrm{C}\left(5^{\circ} \mathrm{C} / \mathrm{min}\right)$, and $240^{\circ} \mathrm{C}(10 \mathrm{~min})$. Data collection was initiated after the hexane solvent was eluted (3.0 min) and continued until no further peaks were observed. All ester-linked FAME phospholipids were identified based on the relative percentage of the ions scanned and by comparison of retention times to the standard qualitative bacterial acid methyl ester mix (Supelco), which ranged from C11 to C20. For each sample, the abundance of individual fatty acid methyl-esters was expressed on a dry-weight basis per unit dry weight. Fatty acid nomenclature was used as described by Frostegård et al. [39-41]. The fatty acids i15:0, a15:0, 15:0, i16:0, 17:0, i17:0, cy17:0, 18:167, and cy 19:0 were chosen to represent bacterial PLFAs (bactPLFAs) [39, 41-43], and 18:2v6 was used as an indicator of fungal biomass (Federle 1986; Kandeler 2000). The ratio of $18: 2 \omega 6$ :bactPLFAs was taken to represent the ratio of fungal: bacterial biomass in the sediment $[41,44]$. Concentrations of individual FAME were determined by calibration with internal standard (methylester C19:0).

\section{Microbial Community Structure Determination}

\section{DNA Extraction and Purification}

Bacterial DNA was extracted following the method of Tsai and Olson [45], with slight modification. The collected bacteria cells were added to $5 \mathrm{~mL}$ of TE buffer $(0.1 \mathrm{M}$ TrisCl, 0.1 M EDTA-Na $, 0.2 \mathrm{M} \mathrm{NaCl}, 2 \%$ CTAB, pH 8.0) and incubated at $37^{\circ} \mathrm{C}$ for $45 \mathrm{~min}$ with agitation (100 rpm). $0.75 \mathrm{~mL}$ of $20 \% \mathrm{SDS}(\mathrm{w} / \mathrm{v})$ was added and followed by a water bath at $65^{\circ} \mathrm{C}$ for $1 \mathrm{~h}$. These samples were centrifuged for $10 \mathrm{~min}$ at $12,000 \mathrm{rpm}$. The supernatant was transferred to a new tube and further extracted twice with an equal volume of phenol-CIAA (phenol:chloroform:isoamyl alcohol, 25:24:1). Finally, nucleic acids in the extracted supernatant were precipitated with sodium acetate (final concentration $0.3 \mathrm{M}, \mathrm{pH} 5.2$ ), and 2.0 volumes of $100 \%$ ethanol for $1 \mathrm{~h}$ at room temperature. A pellet of crude nucleic acids was obtained by 20 min of centrifuging at $12,000 \mathrm{rpm}$. The pellet was washed with $70 \%$ ethanol, dried for $10 \mathrm{~min}$ under a vacuum, and dissolved in $50 \mathrm{~mL}$ TE buffer. 


\section{Primers and PCR Amplification}

The V3 variable region of bacterial $16 \mathrm{~S}$ rDNA was amplified using two primers: F357-GC (5'CGCCCGCCGCGCGCGGCGGGCGGGG CGGGGG CACGGGGGGCCTACGGGAGGCAGCAG -3') and R518 (5'-ATTACCG CGGCTGCTGG-3'). The PCR reaction system $(50 \mu \mathrm{l})$ included $0.5 \mu \mathrm{l}$ template DNA, $0.25 \mu \mathrm{l}$ of Taq polymerase ( $5 \mathrm{U}), 1 \mu \mathrm{l}$ of primers F357-GC $(10 \mu \mathrm{M}), 1 \mu \mathrm{l}$ of R518 $(10 \mu \mathrm{M}), 5 \mu \mathrm{l}$ of tenfold PCR buffer (containing $2.0 \mathrm{mM} \mathrm{MgCl} 2), 1 \mu \mathrm{l}$ of dNTP $(10 \mathrm{mM})$, and $41.25 \mu \mathrm{l}$ of UVsterile water. The following PCR program was used: an initial denaturation at $94^{\circ} \mathrm{C}$ for $4 \mathrm{~min}$, followed by 30 cycles of $94^{\circ} \mathrm{C}$ for $30 \mathrm{~s}, 56^{\circ} \mathrm{C}$ for $1 \mathrm{~min}$, $72^{\circ} \mathrm{C}$ for $30 \mathrm{~s}$, and a final extension at $72^{\circ} \mathrm{C}$ for $7 \mathrm{~min}$. The final extension for $7 \mathrm{~min}$ was performed to eliminate the occurrence of artificial double bands in subsequent DGGE analysis [46].

\section{Denaturing Gradient Gel Electrophoresis (DGGE)}

The expected size of the amplified fragment was 250 bp. DGGE analysis was performed in a DGGE apparatus (Bio-Rad, Richmond, CA, USA). Approximately $400 \mathrm{ng}$ of PCR products were loaded onto an $8.0 \%$ $(\mathrm{w} / \mathrm{v})$ polyacrylamide gel cast in 16TAE buffer. The polyacrylamide gels (acrylamide:bisacrylamide, 37.5:1) were made with denaturing gradients ranging from 30 to $60 \%$. $100 \%$ denaturant contained $7 \mathrm{M}$ urea and $40 \%$ formamide. Electrophoresis was carried out at $60^{\circ} \mathrm{C}$ with a voltage of $150 \mathrm{~V}$ in 16TAE buffer for $4 \mathrm{~h}$. Bands were visualized using a UV transilluminator after staining the gel with ethidium bromide (EB) and photographed.

\section{Cloning and Sequencing}

The dominant bands in the DGGE gel were excised. Each excised piece was washed twice with $1 \mathrm{~mL}$ of sterilized distilled water. A small chip (less than $1 \mathrm{~mm}^{3}$ ) of each piece was used as a direct template for PCR to recover the DNA fragment.

The selective bands on the EB-stained DGGE gel were assigned to different species after their isolation, reamplification by PCR, and sequencing. The selective bands were incised and then placed in a $1.5 \mathrm{~mL}$ tube to reclaim the DNA. DNA was reclaimed using a DNA reclaim kit (Shanghai Sangon: SK1131) according to the manufacturer's instructions. The reclaimed DNA was used as a template to reamplify the bands with the same pair of primers (not containing the GC clamp) and the same PCR conditions as described earlier. Amplicons were then purified by SK1191 UNIQ-10 DNA Gel Extraction Kit (Shanghai Sangon) according to the manufacturer's protocol and sequenced with one of the amplification primers. These sequences were finally compared with similar sequences in the Genbank DNA database using BLAST analysis (basic logical alignment search tool at NCBI) [47].

\section{Multivariable Statistics Analysis}

PCA was performed using CANOCO 4.5 (Biometris, Wageningen, Netherlands) to study the physico-chemical parameters of different sediments and overlying water samples of three reservoirs.

The relationship between phospholipid fatty acid composition and the sediment and overlying water physicochemical properties was also investigated. The initial detrended correspondence analysis (DCA) results demonstrated that the data exhibited linear rather than unimodal response to the environmental variables (most gradient lengths were $0.224,<2$ ) $[48-50]$, so RDA was performed to explain the data by CANOCO 4.5 (Biometris, Wageningen, Netherlands) [45-46]. Ordination biplots including phospholipid fatty acid composition and environmental variables were used to explain the data. The detailed interpretation of ordination plots could be referred to Ter Braak [51].

\section{Results and Discussion}

\section{Water Quality of Overlying Water under Different Hydrostatic Pressures}

Fig. 2 shows the changes in the content of nitrogen of different forms in the overlying water under different hydrostatic pressures. In the early stage of the experiment, simulators under normal pressure and pressure of $0.4 \mathrm{MPa}$ had a higher concentration of $\mathrm{NH}_{4}^{+}$compared with that under $0.9 \mathrm{MPa}$. However, as the reaction proceeded, high hydrostatic pressure had an increasing impact on the interface; in the middle and late stages of the experiment, the concentrations of $\mathrm{NH}_{4}^{+}$in overlying water in the simulators under high hydrostatic pressure was higher than under normal pressure and increased with increasing hydrostatic pressure. The ammoniacal nitrogen releasing was: $0.9 \mathrm{MPa}>0.4 \mathrm{MPa}>$ normal pressure. The accumulation of $\mathrm{NH}_{4}^{+}$in the overlying water at the interface was closely related to DO concentration at the interface; lower DO concentration would help the release of $\mathrm{NH}_{4}^{+}$. Fluctuations in hydrostatic pressure would accelerate dissolved oxygen consumption in the interfacial system [52], and the system under anaerobic conditions. The way $\mathrm{NO}_{3}^{-}$concentration in overlying water increased was contrary to that of $\mathrm{NH}_{4}^{+}$(Fig. 2).

In the middle and late stages of the experiment, the concentration of $\mathrm{NO}_{3}^{-}$under normal pressure was obviously higher than that under high hydrostatic pressure. $\mathrm{NO}_{3}{ }^{-}$concentration showed little difference under 0.4 $\mathrm{MPa}$ and $0.9 \mathrm{MPa}$ pressure; the $\mathrm{NO}_{3}^{-}$concentration under $0.4 \mathrm{MPa}$ was slightly higher than under $0.9 \mathrm{MPa}$. Taking the changes of $\mathrm{NH}_{4}^{+}$into consideration, we may know that, under normal pressure, the concentration of $\mathrm{NH}_{4}^{+}$in overlying water lowers while that of $\mathrm{NO}_{3}^{-}$goes up, and that $\mathrm{NH}_{4}^{+}$concentration increases as $\mathrm{NO}_{3}^{-}$level decreases under high hydrostatic pressure. In other words, high hydrostatic pressure is of help for ammonification 


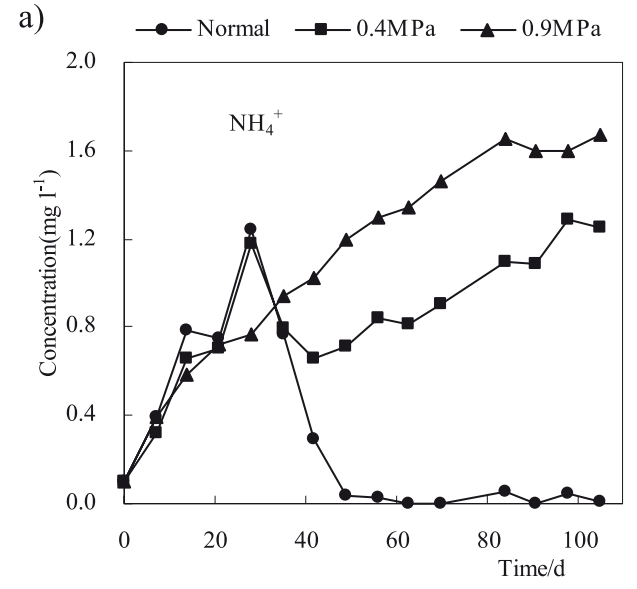

c)

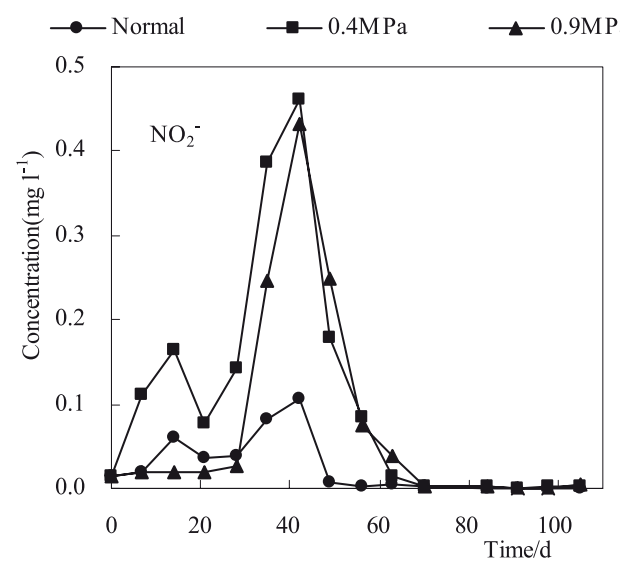

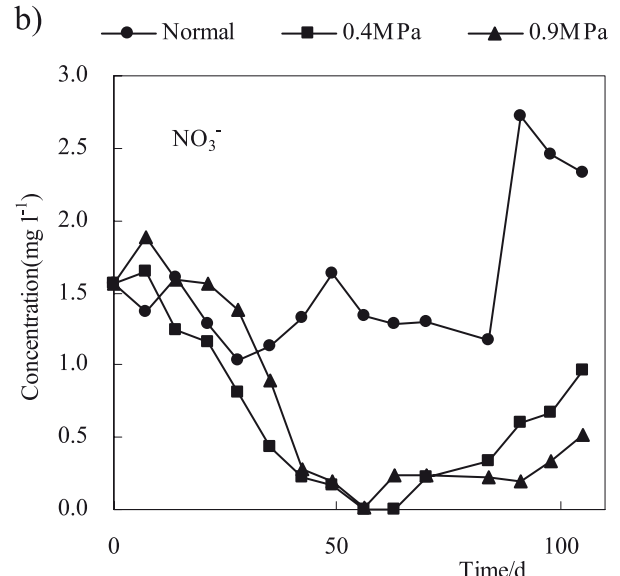

d)

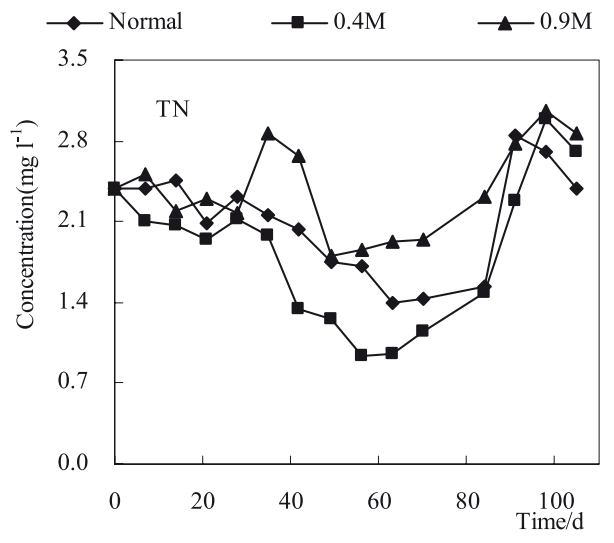

Fig. 2. Nitrogen concentration changes of different forms in overlying water.

and normal pressure for nitrification. On the other hand, ammonification and nitrification will be affected by such factors as DO concentration at the interface, $\mathrm{NO}_{3}^{-}$ concentration, microorganism composition, and activity, which will change as hydrostatic pressure alters. Therefore, the changes in the concentration of $\mathrm{NH}_{4}^{+}$and $\mathrm{NO}_{3}^{-}$are the results of both the impacts of hydrostatic pressure and other environmental factors. From Fig. 2 we can see the changes in $\mathrm{NO}_{2}$ - concentration in the overlying water.

In the early and middle stages of the experiment, the overlying water in three simulators witnessed an accumulation of nitrite nitrogen, which accumulated more under high hydrostatic pressure than under normal pressure. The main reason was that, at this stage, a large amount of $\mathrm{NH}_{4}^{+}$was released and nitrifying bacteria was not able to oxidize $\mathrm{NO}_{2}^{-}$from the oxidation of nitrosobacteria by ammoniacal nitrogen completely at the time. As the reaction proceeded, $\mathrm{NO}_{2}{ }^{-}$was oxidized gradually to nitrate nitrogen by nitrifying bacteria. In the late stage, the concentration of $\mathrm{NO}_{2}^{-}$in all simulators was close to zero and there was no accumulation. In the simulation experiment, the total released nitrogen going to the overlying water was composed of ammoniacal nitrogen and nitrate nitrogen and different hydrostatic pressures had a bearing on their release. The impact on the release of total nitrogen (TN) was the result of ammoniacal nitrogen and nitrate nitrogen being affected. It can be seen in Fig. 2 that there was not much difference among three simulators in terms of the TN concentration in the overlying water except that the concentration of TN under high hydrostatic pressure was slightly higher that under normal pressure. Nitrogen cycle in the interfacial system is complicated and the content of nitrogen of different forms in overlying water is the result of biogeochemical reaction. Furthermore, different hydrostatic pressures will cause changes in the composition of microbial communities of the system [53] and will affect the activity of microorganisms and enzymes, and their biological functions [27, 54]. Thus, it is necessary to further discuss the influences of hydrostatic pressure on the interface by considering enzyme activity in the sediments under different hydrostatic pressures, and the composition and functional changes of microbial communities.

\section{Sediment Nitrogen Load and Enzyme Activities under Different Hydrostatic Pressures}

Fig. 3 shows the content of total nitrogen in sediments after the simulation experiment: normal pressure $>0.4$ $\mathrm{MPa}>0.9 \mathrm{MPa}$. The result demonstrated that the simulator under $0.9 \mathrm{MPa}$ pressure witnessed the biggest decrease in total nitrogen amount in the sediment and the highest 


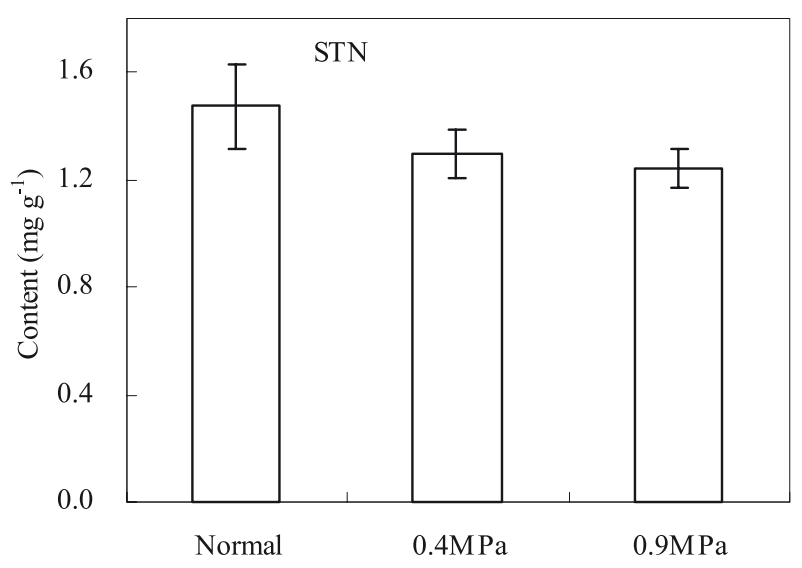

Fig. 3. STN content in sediment under different hydrostatic pressures.

content of nitrogen released into the overlying water, which was consistent with the analysis of overlying water quality in Fig. 3. So, when the hydrostatic pressure was between $0.1-1.0 \mathrm{MPa}$, it stimulated the release of nitrogen in the sediment, making more nutrients involved in interfacial nitrogen cycle. However, if the large amount of nitrogen released could not be degraded by other microorganisms to the form of gas or other harmless forms, it would greatly impact the overlying water quality, and then the ecological environment of reservoir through eutrophication.

The nitrogen cycle at the interface is closely related to microorganisms. The activity of enzymes in microbial cells in sediment may effectively represent the functional activity of microorganisms and can be used to evaluate the transformation of nutrients in the sediment. A comparative analysis was made on enzyme activity of surface-sediment microorganisms under different hydrostatic pressures after the simulation experiment, and the result was shown in Fig. 4. When under hydrostatic pressure of $0.9 \mathrm{MPa}$, the activity of dehydrogenases, proteases, ureases, and nitrate reductases was higher than under $0.4 \mathrm{MPa}$ and normal pressure; when under hydrostatic pressure of $0.4 \mathrm{MPa}$, the activity of dehydrogenases and proteases was higher than that under normal pressure, while there was not much difference in ureases and nitrate reductases. Thus when hydrostatic pressure was controlled within 0.1-1.0 MPa, the activity of dehydrogenases and proteases would increase as the pressure rose; however, pressure of $0.4 \mathrm{MPa}$ was not enough to increase the activity of ureases and nitrate reductases in an obvious fashion, and a minor increase in their activity would take place when the pressure went up to $0.9 \mathrm{MPa}$.

Some researches has shown that high pressure within a certain range could make the microbial enzymes more stable and could increase their activity (Michael, 2009). From the experiment result we can see that when hydrostatic pressure was within the range from 0.1-1.0 MPa, a higher hydrostatic pressure could significantly increase the activity of dehydrogenases and proteases, but affected ureases and nitrate reductases less.

The pressure-induced effect on the enzyme-catalyzed reaction rate may be explained from three aspects: 1) pressure changes the structure of a certain enzyme directly, 2) pressure induces changes in the enzymatic reaction mechanism, such as altering the rate-determining step,

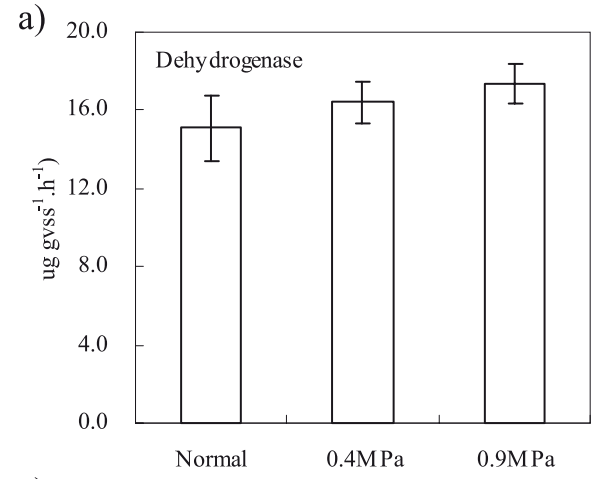

c)

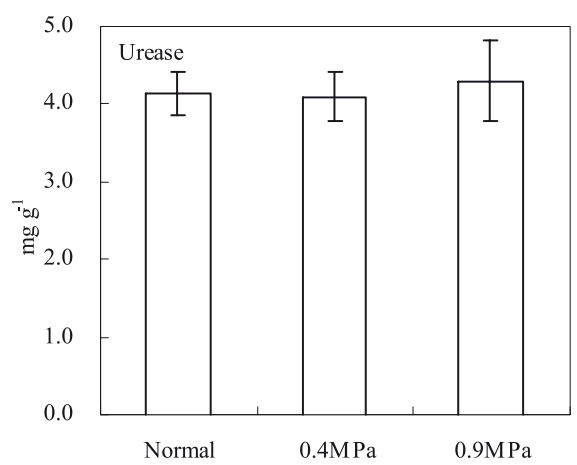

b)

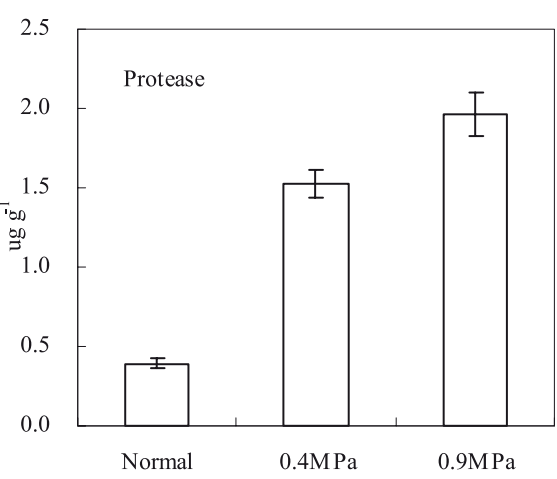

d)

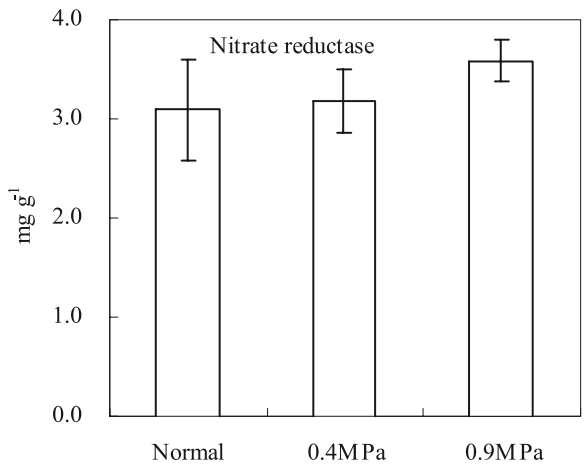

Fig. 4. Sediment enzyme activities under different hydrostatic pressures. 
Table 1. Enzymes whose activities might increase due to the pressure-induced effect.

\begin{tabular}{|c|c|c|}
\hline Category & Specific name & $\begin{array}{l}\text { EC:enzyme } \\
\text { commission }\end{array}$ \\
\hline \multirow{5}{*}{$\begin{array}{l}\text { Oxidoreductases } \\
\text { (EC1) }\end{array}$} & Dehydrogenase & EC 1.1.1.1 \\
\hline & Hydrogenase & EC 1.1.1.2 \\
\hline & Peroxidase & $1.11 .1 .1-16$ \\
\hline & Lipoxygenase & EC 1.13.11.12 \\
\hline & Polyphenoloxidase & EC 1.14.18.1 \\
\hline Transferases (EC2) & Polymerase & 2.7.7.7 \\
\hline \multirow{19}{*}{ Hydrolases (EC3) } & $\begin{array}{c}\text { Pectin } \\
\text { methylesterase }\end{array}$ & EC 3.1.1.11 \\
\hline & Lipase & EC 3.1.1.3 \\
\hline & Acetylcholinesterase & EC 3.1.1.7 \\
\hline & Polygalacturonase & EC 3.2.1.15 \\
\hline & $\alpha$-Amylase & EC 3.2.1.1 \\
\hline & $\beta$-Amylase & EC 3.2.1.2 \\
\hline & $\beta$-Glucanase & EC 3.2.1.2 \\
\hline & Glucoamylase & EC 3.2.1.3 \\
\hline & Lysozyme & EC 3.2.1.17 \\
\hline & $\beta$-Glucosidase & EC 3.2.1.21 \\
\hline & $\beta$-Galactosidase & EC 3.2.1.23 \\
\hline & Invertase & EC 3.2.1.26 \\
\hline & Naringinase & EC 3.2.1.40 \\
\hline & Myrosinase & EC 3.2.3.1 \\
\hline & $\alpha$-Chymotrypsin & EC 3.4.21.1 \\
\hline & Thermolysin & EC 3.4.24.27 \\
\hline & Pepsin & EC 3.4.23.1 \\
\hline & $\begin{array}{l}\text { Unidentified } \\
\text { protease }\end{array}$ & \\
\hline & Pyrophosphatase & 3.6.1.1 \\
\hline Lyases (EC4) & Aspartase & 4.3.1.1 \\
\hline
\end{tabular}

and 3) pressure changes the physicochemical properties of the substrate or solvent $(\mathrm{pH}$, density, viscosity, phase behavior, etc.), and further changes the enzyme structure or rate-determining rate of enzymatic reaction [27]. In addition to those representative enzymes tested in the experiment, there were still many enzymes whose activity might increase due to pressure-induced effect (Table 1). Thus an increase of activity in various enzymes of microorganisms in the interfacial system and in their corresponding microbial functions under high hydrostatic system could cause the nitrogen cycle to be presented in different patterns of change, and therefore cause significant differences in the overlying water quality. High hydrostatic pressure, evidently, facilitated the release of nitrogen

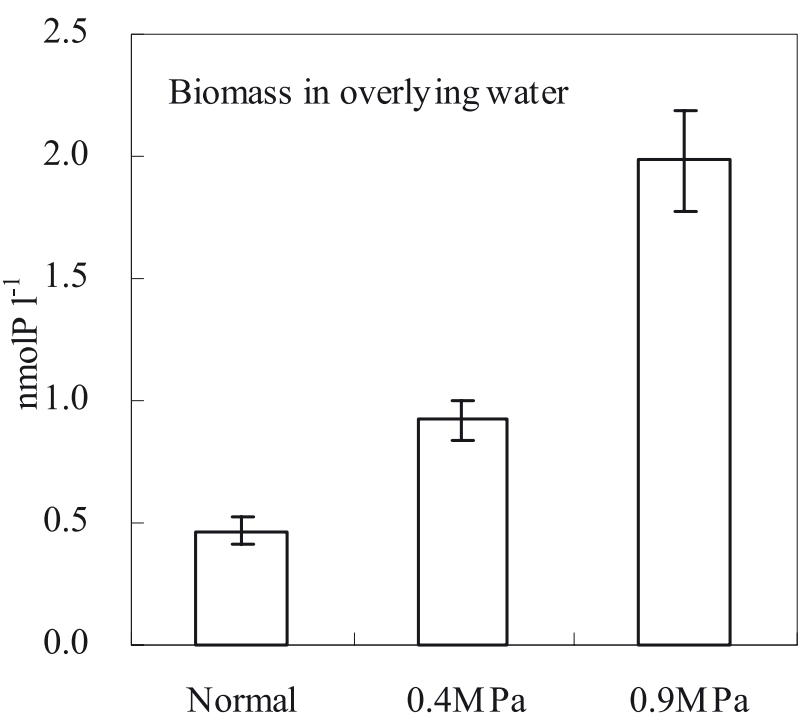

Fig. 5 Biomass in overlying water under different hydrostatic pressure.

(Fig. 2), but had little influence on nitrate reductases important in denitrification. So high hydrostatic pressure was not an advantage for denitrification and could not help with nitrogen loading degradation in sediment radically. And the quality of overlying water would, as a result, be affected by a significant accumulation of or a large amount of ammoniacal nitrogen releasing to the overlying water or by the nitrate nitrogen transforming from ammoniacal nitrogen for changes in a reducing environment and water oxidation, which could not be removed completely through denitrification.

\section{Microbial Community Diversity under Different Hydrostatic Pressures}

The biomass in the overlying water was tested using the lipid-P method. Fig. 5 shows the result that biomass in the overlying water under high hydrostatic pressure was more than that under normal pressure and demonstrated an increasing tendency as high hydrostatic pressure rose.

It can be seen from the results that, under different hydrostatic pressures, the overlying water quality, total nitrogen in sediment, and the activity of microbial enzymes were remarkably different. To further discuss how hydrostatic pressure affects interfacial material cycle, PLFA methods were used in the comparative analysis on the diverse structure of microbial communities in the sediment under different hydrostatic pressures. The determination and results were shown in Fig. 6 and Table 2. From Table 2 we can see that, under high hydrostatic pressure, both the total PLFA content and the range and number of PLFAs detected were higher than under normal pressure. Total PLFA content, under pressures of $0.4 \mathrm{MPa}$ and $0.9 \mathrm{MPa}$, was $87.63 \%$ and $68.29 \%$ higher than under normal pressure, respectively. Under the three hydrostatic pressures, C23:0 was the major player of the PLFA community, accounting for, respectively, 83.99\%, 
Table 2. PLFA content in the sediment samples under different hydrostatic pressures.

\begin{tabular}{|c|c|c|c|}
\hline & GY0 & GY0.4 & GY0.9 \\
\hline $\begin{array}{c}\text { Total PLFAs } \\
(\mathrm{nmol} / \mathrm{g})\end{array}$ & 11651.44 & 21861.81 & 19608.27 \\
\hline $\begin{array}{c}\sum \mathrm{SFA}^{*} \\
(\mathrm{nmol} / \mathrm{g})\end{array}$ & 11597.62 & 21804.26 & 19581.13 \\
\hline $\begin{array}{c}\sum \mathrm{MUFA} \\
\text { (nmol/g) }\end{array}$ & 53.81 & 57.55 & 27.13 \\
\hline PLFA range & $\mathrm{C} 14: 0 \sim \mathrm{C} 23: 0$ & $\mathrm{C} 13: 0 \sim \mathrm{C} 24: 0$ & $\mathrm{C} 14: 0 \sim \mathrm{C} 24: 0$ \\
\hline $\begin{array}{c}\text { PLFA } \\
\text { quantity }\end{array}$ & 13 & 13 & 15 \\
\hline
\end{tabular}

${ }^{*} \sum$ SFA: saturated fatty acid, ${ }^{* *} \sum$ MUFA: monounsaturated fatty acid

$88.02 \%$, and $90.48 \%$ of total PLFA content. And the number increased as the pressure went up, which meant that high hydrostatic pressure facilitated the increase in the number of PLFAs.

A principal component analysis (PCA) was made on PLFAs in the sediment microbiota under different hydrostatic pressures. The results are shown in Fig. 7, and the differences were significant, that is normal pressure, and pressures of $0.4 \mathrm{MPa}$ and $0.9 \mathrm{MPa}$ were in second, fourth, and third quadrants, respectively. The first principal component accounted for $60.8 \%$ of the total differences

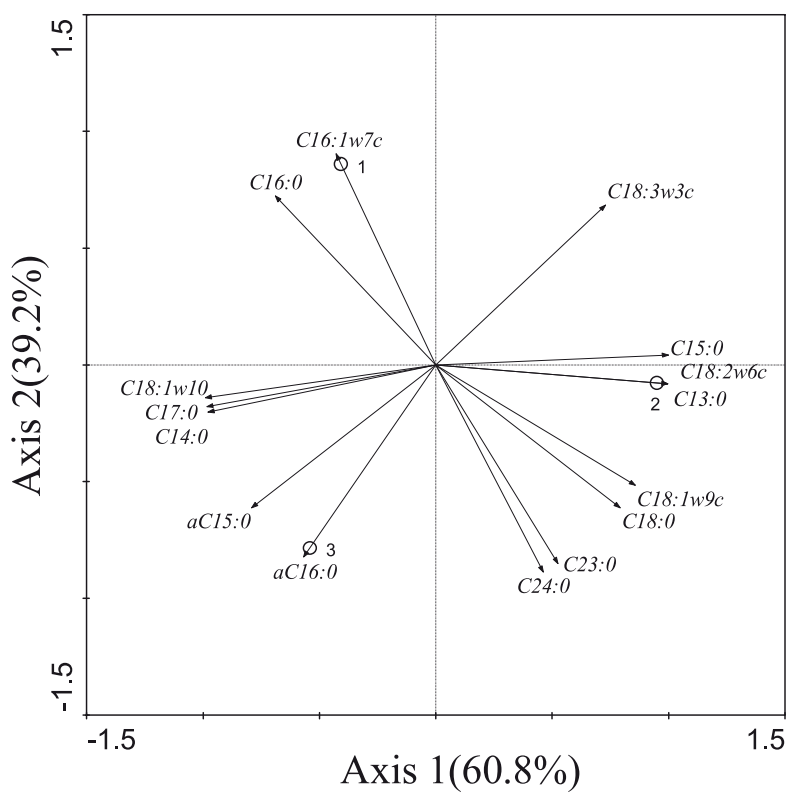

Fig. 7 PCA of the PLFAs in sediments under different hydrostatic pressure (1:GY0;2:GY0.4;3:GY0.9).

and the second principal component $39.2 \%$, explaining the total differences. The contribution by PLFAs to first and second principal component was depicted in Fig. 7. The smaller the axis angle of principal component, the more contributions PLFAs made to it.

a)

GY0

b)

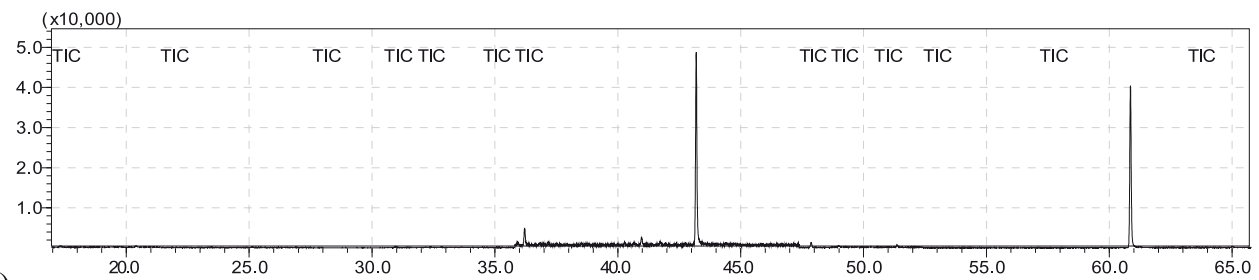

GY0.4

c)

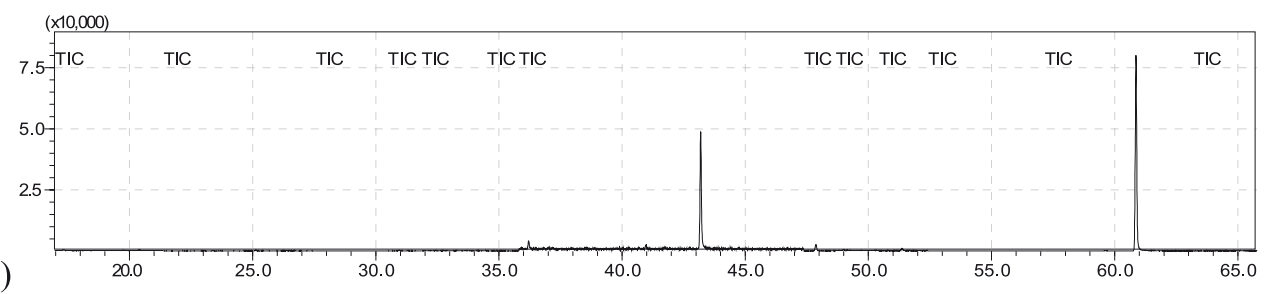

GY0.9

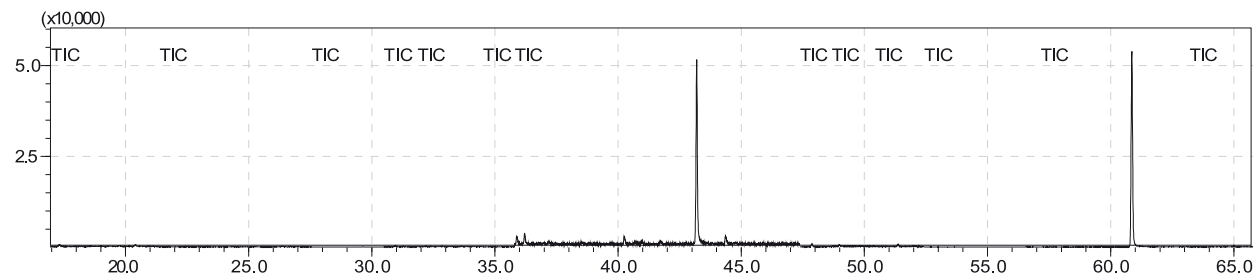

Fig. 6. GC/MS chromatogram of PLFAs in sediment under different hydrostatic pressures. 


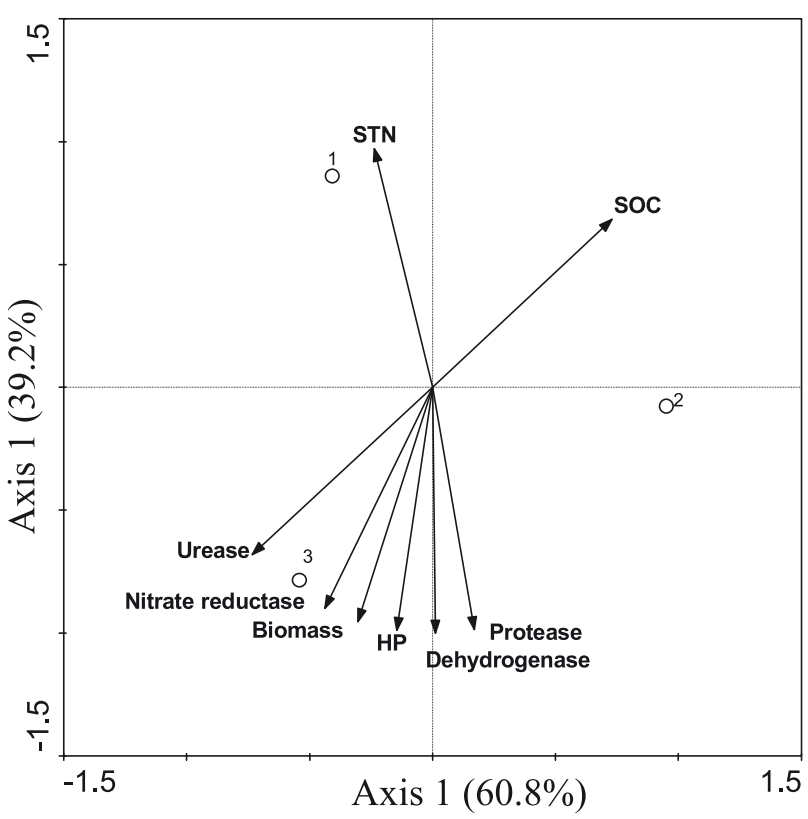

Fig. 8. Ordination diagram of phospholipids fatty acid composition associated with the other parameters of urease, nitrate reductase, dehydrogenase, protease, biomass, and hydrostatic pressure (HP). Other parameters are indicated as arrows. Phospholipid fatty acid samples are indicated as a circle. (०,1:GY0;2:GY0.4;3:GY0.9)

After detrended correspondence analysis (DCA), the most length of gradient of PLFA under normal pressure, $0.4 \mathrm{MPa}$ and $0.9 \mathrm{MPa}$, was $0.814<2$. Thus the linear model, or redundancy analysis (RDA), was used to analyze how environmental factors affected microbiota

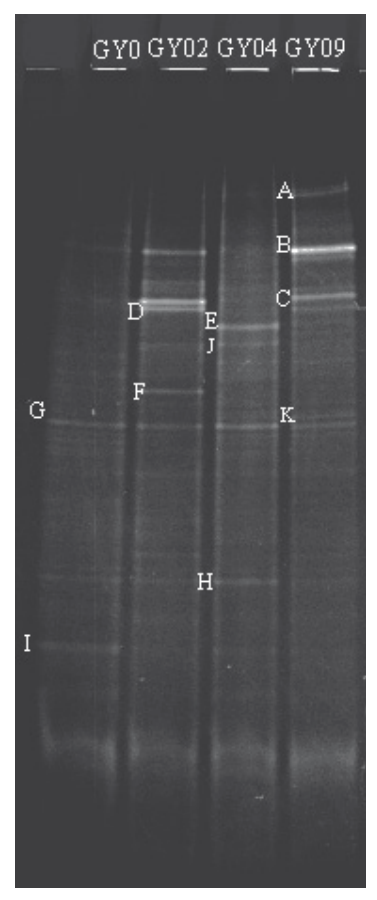

Fig. 9. DGGE profiles of sediment samples under different hydrostatic pressures. structure and contributed to the differences. And the result is shown in Fig. 8. Environmental factors like hydrostatic pressure, dehydrogenases, proteases, and total nitrogen in sediment contributed most to the differences in microbiota structure in sediments, among which hydrostatic pressure, dehydrogenases, and proteases showed a significantly negative correlation with the second principal component, while total nitrogen in the sediment saw a positive correlation with the second principal component. From the analysis, it is known that dehydrogenases, proteases, and other microorganism enzymes were influenced by hydrostatic pressure, whose activity would change as the pressure changed. Therefore, hydrostatic pressure was the most important factor affecting microbiota structures in the sediment.

After amplifying the DNA extracted from microorganisms in sediment samples by PCR and segregation analysis on the amplified product performed by DGGE, we can get a legible diagram of DGGE of microorganisms in the sediment under different hydrostatic pressures (Fig. 9). From Figure 10, it is known that there were significant differences in the number and location of DGGE bands under different hydrostatic pressures. When the pressure rose, the number of bands increased. Compared with the one under normal pressure, the one under 0.4 MPa had two more bands, that is E and $\mathrm{J}$, and band $\mathrm{H}$ had a stronger signal. For the one under pressure of $0.9 \mathrm{MPa}$, there were four more bands, including A, B, $\mathrm{C}$, and $\mathrm{K}$, while band $\mathrm{B}$, was notably larger and brighter, indicating that its corresponding microbial species was the dominant one, which was not detected when the pressure was normal and 0.4 MPa. Apparently, it was a new species occurring when the pressure was $0.9 \mathrm{MPa}$.

From the biodiversity index of microorganisms in the sediment samples shown in Table 3, we can see that, the Simpson and Shannon indexes, when the pressure was $0.9 \mathrm{MPa}$, were higher than those under normal pressure and $0.4 \mathrm{MPa}$. The two indexes have been widely used in statistics to reflect diversity of the microbiota structure. Table 3 tells us that, from the perspective of statistics, compared with normal pressure, the diversity of the microorganism community did not increase significantly under $0.4 \mathrm{MPa}$ pressure. Thus, when the range of hydrostatic pressure was from $0.1-1.0 \mathrm{MPa}$, the diversity of microbiota structure would not remarkably increase and new species would not appear until the pressure went up a certain degree.

Table 4 showed the results of a similarity analysis of DGGE fingerprints under different hydrostatic pressures.

Table 3. Biodiversity index of microorganisms in the sediment samples under different hydrostatic pressures.

\begin{tabular}{|c|c|c|}
\hline & Simpson Index & Shannon Index \\
\hline Normal(GY0) & 0.800 & 1.609 \\
\hline $0.4 \mathrm{MPa}(\mathrm{GY04})$ & 0.800 & 1.609 \\
\hline $0.9 \mathrm{MPa}(\mathrm{GY} 09)$ & 0.857 & 1.946 \\
\hline
\end{tabular}


Table 4. Similarity analysis of DGGE fingerprints under different hydrostatic pressures.

\begin{tabular}{|c|c|c|c|}
\hline & GY0 & GY04 & GY09 \\
\hline Normal (GY0) & 100 & & \\
\hline $0.4 \mathrm{MPa}(\mathrm{GY} 04)$ & $60 \%$ & 100 & \\
\hline $0.9 \mathrm{MPa}(\mathrm{GY} 09)$ & $50 \%$ & $33.3 \%$ & 1 \\
\hline
\end{tabular}

There was a similarity of $60 \%$ between $0.4 \mathrm{MPa}$ and normal pressure, $50 \%$ between $0.9 \mathrm{MPa}$ and normal pressure, and $33.3 \%$ between 0.9 and $0.4 \mathrm{MPa}$. We may see that, therefore, microbiota structure in sediments under $0.4 \mathrm{MPa}$ was more similar to that under normal pressure and more different from the one under $0.9 \mathrm{MPa}$. The reason behind was that, first, within the range of $0.1-1.0 \mathrm{MPa}$, higher hydrostatic pressure had greater influence on the structure; in addition, the sediments in this experiment were from Heihe Reservoir, which had a greater average depth, and thus there were more microorganism communities adapted to high hydrostatic pressure in the sediment, leading to a richer diversity of microorganism communities under high hydrostatic pressure.

Eleven representative bands were selected (bands A to $\mathrm{K}$ ) from the DGGE bands under different hydrostatic pressures after segregation, among which bands $\mathrm{D}$ and $\mathrm{F}$ were found when the pressure was $0.2 \mathrm{MPa}$. After tapping the bands and eluting and recycling the DNA, the recycled DNA was amplified by PCR and tested by electrophoresis. For those re-amplified bands, after purification, connection, transformation, cloning, and sequencing, a homology search and BLAST search were conducted on their sequencing results to identify the bacterial genus most closely related to each corresponding band. From the

Table 5. Sequencing results for representatives of the DGGE bands under different HP.

\begin{tabular}{|c|c|c|}
\hline No. & $\begin{array}{c}\text { Sequence } \\
\text { length } / \mathrm{bp}\end{array}$ & Bacterial genus \\
\hline $\mathrm{A}(\mathrm{GY09})$ & $189 \mathrm{bp}$ & Flavobacterium $\mathrm{sp}$. \\
\hline $\mathrm{B}(\mathrm{GY09})$ & $189 \mathrm{bp}$ & Flavobacterium xinjiangense \\
\hline \multirow{2}{*}{ C(GY09) } & $194 \mathrm{bp}$ & Massilia brevitalea \\
\cline { 2 - 3 } & $189 \mathrm{bp}$ & Flavobacterium columnare \\
\hline $\mathrm{D}(\mathrm{GY02})$ & $169 \mathrm{bp}$ & Acidobacteriaceae bacterium \\
\hline $\mathrm{E}(\mathrm{GY04})$ & $194 \mathrm{bp}$ & Gallionella $\mathrm{sp}$. \\
\hline $\mathrm{F}(\mathrm{GY02})$ & $194 \mathrm{bp}$ & Rhodoferax $\mathrm{sp}$ \\
\hline $\mathrm{G}(\mathrm{Normal})$ & $169 \mathrm{bp}$ & Chloroflexi bacterium \\
\hline $\mathrm{H}(\mathrm{GY04})$ & $186 \mathrm{bp}$ & Nitrospira $\mathrm{sp}$ \\
\hline $\mathrm{I}($ Normal $)$ & $184 \mathrm{bp}$ & Nitrospira $\mathrm{sp}$ \\
\hline $\mathrm{J}(\mathrm{GY04})$ & $194 \mathrm{bp}$ & Methylotenera \\
\hline K(GY09) & $194 \mathrm{bp}$ & Gallionella $\mathrm{sp}$ \\
\hline
\end{tabular}

results in Table 5, bands $\mathrm{A}, \mathrm{B}$, and $\mathrm{C}$ were the new ones under $0.9 \mathrm{MPa}$ belonging to the genus Flavobacterium sp, genus Flavobacterium xinjiangense, genus Massilia brevitalea and Flavobacterium columnare respectively. Though the sequencing length and location of band $\mathrm{H}$ was subjected to $0.4 \mathrm{MPa}$ and band I was subjected to normal pressure, they turned out to belong to the same genus after cloning and sequencing. Therefore, the newly added bands under normal pressure were $\mathrm{E}$ and $\mathrm{J}$, belonging to genus Gallionella sp. and Methylotenera, respectively.

\section{Conclusions}

The simulation experiment in a laboratory studied the effects of 0.1-1.0 MPa hydrostatic pressure on material cycles at the interface and conclusions are addressed as follows:

1) When the hydrostatic pressure is $0.1-1.0 \mathrm{MPa}$, it facilitates the release of nitrogen at the interface and ammonification, but has little influence on denitrification. The pressure within the range will also cause a large accumulation of such pollutants as ammoniacal nitrogen and nitrate nitrogen at the interface, seriously worsening the overlying water quality.

2) High hydrostatic pressure will significantly increase the activity of dehydrogenases and proteases in the sediment, and has little influence on ureases and nitrate reductase activity.

3) As PLFA and PCR-DGGE analysis results show, different hydrostatic pressures will lead to remarkably different structures and heredities within the microbial community. When the pressure is within the range of $0.1-1.0 \mathrm{MPa}$, the microbial community structure is more diverse under high hydrostatic pressure than under normal pressure.

\section{Acknowledgements}

Part of our experiments were carried out in the Key Laboratory of Northwest Water Resource, Environment, and Ecology, MOE. This research work is financially supported by a Program of the International S\&T Cooperation of China (No. 2010DFA94550) and the National Natural Science Foundation of China (NSFC, No. 51509199 and No.50830303). The authors would like to express their gratitude to the agencies involved and to the participants in the study.

\section{References}

1. LEWIS W.M., WURTSBAUGH W. A., PAERL H.W. Rationale of control of anthropogenic nitrogen and phosphorus to reduce eutrophication of inland waters. Environ. Sci. Technol. 45, 10300, 2011.

2. ZHENMING ZHOU, TINGLIN HUANG, BAOLING YUAN, AND XIAOBIN LIAO Remediation of itrogen- 
Contaminated Sediment Using Bioreactive, Thin-layer Capping with Biozeolite. SOIL AND SEDIMENT CONTAMINATION, 25 (1), 89, 2016. doi:10.1080/153203 83.2016.1090947

3. GAWROŃSKA H., BRZOZOWSKA R., GROCHOWSKA J., LOSSOW K. Possibilities to Reduce Internal Loading to Lake Water by Artificial Aeration. Polish Journal of Environmental Studies, 12 (2), 171, 2003.

4. PAN G., DAI L.C., LI L., HE L.C., LI H., BI L.,GULATI R.D. Reducing the recruitment of sedimented algae and nutrient release into the overlying water using modified soil/ sand flocculation-capping in eutrophic lakes. Environ. Sci. Technol. 46, 5077, 2012.

5. TANG X.Q., WU M., YANG W.J., YIN W., JIN F., YE M., CURRIE N., SCHOLZ M. Ecological strategy for eutrophication control. Water Air Soil Poll. 223 (2), 723, 2012.

6. BALLNTINE D.J., WALLING D.E., COLLINS A.L., LEEKS G.J.L. The phosphorus content of fluvial suspended sediment in three loweland groundwater-dominated catchments. J. Hydrol., 357, 140, 2008.

7. IGLESIAS M.L., DEVESA-REY R., PEREZ-MOREIRA R., DIAZ-FIERROS F., BARRAL M.T. Phosphorus transfer across boundaries: from basin soils to river bed sediments. J. Soil Sediments, 11, 1125, 2011.

8. SMAL H., LIGĘZA S., BARAN S., WÓJCIKOWSKAKAPUSTA A., OBROŚLAK R. Nitrogen and Phosphorus in Bottom Sediments of Two Small Dam Reservoirs. Pol. J. Environ. Stud., 22 (5), 1479, 2013.

9. FENECH C., ROCK L., NOLAN K., TOBIN J., MORRISSEY A. The potential for a suite of isotope and chemical markers to differentiate sources of nitrate contamination: a review. Water Res. 46, 2023, 2012.

10. HUANG T.L., LI X., RIJNAARTS H., GROTENHUIS T., MA W.X., SUN X., XU J.L.. Effects of storm runoff on the thermal regime and water quality of a deep, stratified reservoir in a temperate monsoon zone, in Northwest China. Sci. Total Environ. 485-486, 820, 2014.

11. TINGLIN HUANG, LIN GUO, HAIHAN ZHANG, JUNFENG SU, GANG WEN, KAI ZHANG Nitrogenremoval efficiency of a novel aerobic denitrifying bacterium, Pseudomonas stutzeri strain ZF31, isolated from a drinkingwater reservoir. Bioresource Technology, 196, 209, 2015.

12. WANG L., TAO LIANG, BUQING ZHONG, KEXIN LI, QIAN ZHANG, CHAOSHENG ZHANG Study on Nitrogen Dynamics at the Sediment-Water Interface of Dongting Lake, China. Aquat Geochem 20, 501, 2014. doi:10.1007/s10498-014-9232-0

13. LEI CHEN, TIANYUAN ZHENG, JUNJIE ZHANG, JIE LIU AND XILAI ZHENG Effective control of modified palygorskite to $\mathrm{NH}+4-\mathrm{N}$ release from sediment. Environmental Technology, 35 (1), 60, 2014. doi: 10.1080/09593330.2013.808268

14. LIU C.G., JIN X.C., SUN L., SUN H.W., ZHU L., YU Y., DAI G.S., ZHUANG Y.Y. Effects of nitrogen source and aeration mode on algae growth in freshwater. Environ Sci., 27, 101, 2006.

15. JIANWEI ZHAO, DUANWEI ZHU, JUNNAN FAN, YUMEI HUA, WENBING ZHOU Seasonal Variation of Anammox and Denitrification in Sediments of Two Eutrophic Urban Lakes. Pol. J. Environ. Stud. 24 (6), 2779, 2015. DOI: $10.15244 /$ pjoes $/ 59237$

16. WU Y.C., XIANG Y., WANG J.J., WU Q.L. Molecular detection of novelAnammox bacterial clusters in the sediments of the shallow freshwater Lake Taihu. Geomicrobiol J 29, 852, 2012. doi: 10.1080/01490451.2011.635760.
17. HAI-HAN ZHANG, TING-LIN HUANG, SHENG-NAN CHEN XIAO YANG, KAI LV, RAJU SEKAR Abundance and Diversity of Bacteria in Oxygen Minimum Drinking Water Reservoir Sediments Studied by Quantitative PCR and Pyrosequencing. Microb Ecol. 68 (4), 2014. DOI 10.1007/ s00248-014-0539-6

18. RÖSKE K., ROSKE I., UHLMANN D. Characterization of the bacterial population and chemistry in the bottom sediment of a laterally subdivided drinking water reservoir system. Limnologica 38, 367, 2008.

19. RÖSKE K., SACHSE R., SCHEERER C. Microbial diversity and composition of the sediment in the drinking water reservoir Saidenbach (Saxonia, Germany). Syst Appl Microbiol 35, 35, 2012.

20. ZHANG H.H., HUANG T.L., LIU T.T. Sediment enzyme activities and microbial community diversity in an oligotrophic drinking water reservoir, eastern China. PLoS ONE, 8 (10), e 78571, 2013.

21. KRANZIOCH I., STOLL C., HOLBACH A., CHEN H., WANG L., ZHENG B. Dechlorination and organohaliderespiring bacteria dynamics in sediment samples of the Yangtze Three Gorges Reservoir. Environ Sci Pollut Res 20, 7046, 2013.

22. LIU J., LIN Z., ZHANG H., HAN B.P. Hydrodynamic change recorded by diatoms in sediments of Liuxihe Reservoir, southern China. J Paleolimnol 47, 17, 2012.

23. ZHANG H.H., HUANG T.L., CHEN S.N., GUO L., YANG $\mathrm{X}$. Microbial community functional diversity and enzymatic activity in the sediments of drinking water reservoirs, Northwest China. Desalin Water Treat 52, 1608, 2014.

24. NEWTON R.J., JONES S.E., EILER A., MCMAHON K.D., BERTILSSON S. A guide to the natural history of freshwater lake bacteria. Microbiol. Mol. Biol. Rev. 75, 14, 2011.

25. XIAO YANG, TINGLIN HUANG AND HAIHAN ZHANG Effects of Seasonal Thermal Stratification on the Functional Diversity and Composition of the Microbial Community in a Drinking Water Reservoir. Water, 7, 5525, 2015. doi: 10.3390/w7105525

26. AUDE PICARD, ISABELLE DANIEL Pressure as an environmental parameter for microbial life - A review. Biophysical Chemistry 183, 30, 2013.

27. MICHAEL J.E., REYES-DE-CORCUERA J.I. High pressure enhancement of enzymes: A review. Enzyme Microb. Tech. 45, 331, 2009.

28. XU K., BINGUANG M. Comparative analysis of predicted gene expression among deep-sea genomes. Gene 397, 136, 2007.

29. PHILIPPE M., OGER M. JEBBAR. The many ways of coping with pressure. Res. Microbiol. 161, 799, 2010.

30. TAMBURINI C., GOUTX M., GUIGUE C., GAREL M., LEFE 'VRE D. Effects of hydrostatic pressure on microbial alteration of sinking fecal pellets. Deep-Sea Res. Pt. II 56, $1533,2009$.

31. RIVALAIN N., ROQUAIN J., DEMAZEAU G. Development of high hydrostatic pressure in biosciences: Pressure effect on biological structures and potential applications in Biotechnologies. Biotechnol. Adv. 28, 659, 2010.

32. AUDE PICARD, DENIS TESTEMALE, JEAN-LOUIS HAZEMANN, ISABELLE DANIEL The influence of high hydrostatic pressure on bacterial dissimilatory iron reduction. Geochimica et Cosmochimica Acta 88, 120, 2012.

33. WU W.F., WANG F.P., LI J.H., YANG X.W., XIAO X., PAN Y.X.. Iron reduction and mineralization of deep-sea iron reducing bacterium Shewanella piezotolerans WP3 at elevated hydrostatic pressures. Geobiology 11, 593, 2013. 
34. WINTER R., JEWORREK C. Effect of pressure on membranes. Soft Matter 5, 3157, 2009.

35. BEI-BEI CHAI, TING-LIN HUANG, XIAO-GUANG ZHAO AND YA-JIAO LI Phospholipids Fatty Acids of Three Drinking Water Reservoir Sedimentary Microbial Community: Structure and Function responses to Different Hydrostatic Pressure and Other Physicochemical Properties. Journal of Environmental Biology, 36, 845, 2015.

36. China State Environmental Protection Agency: Standard Methods for the Examination of Water and Wastewater. 34 China State Environmental Protection Agency, Beijing, China, 2002 [In Chinese].

37. GUAN S.Y. Soil enzyme and its research method. Beijing: Agriculture Press. 1983.

38. BLIGH E.G., DYER W.J. A rapid method of total lipid extraction and purification. Can. J. Biochem. Physiol. 37 (8), 911, 1959.

39. FROSTEGÅRD ÅSA (A.), BÅ̊̊TH E., TUNLID A. Shifts in the structure of soil microbial communities in limed forests as revealed by phospholipid fatty acid analysis. Soil Biol Biochem 25, 723, 1993.

40. FROSTEGÅRD ÅsA (A.), TUNLID A., BÅATH E. Phospholipid fatty acid composition and activity of microbial communities from two soil types experimentally exposed to different heavy metals. Appl Environ Microbiol 59, 3605, 1993.

41. KANDELER E., TSCHERKO D., BRUCE K.D., STEMMER M., HOBBS P.J., BARDGETT R.D., AMELUNG W. Structure and function of the soil microbial community in microhabitats of a heavy metal polluted soil. Biol Fertil Soils 32, 390, 2000.

42. FEDERLE T.W. Microbial distribution in soil - new techniques. In: Megusar F, Gantar M (eds) Perspectives in microbial ecology. Slovene Soc Microbiol, Ljubljana, 493, 1986.

43. TUNLID A., HOITINK HAJ, LOW C., WHITE D.C. Characterization of bacteria that suppress Rhizoctonia damping-off in bark compost media by analysis of fatty acid biomarkers. Appl Environ Microbiol 55, 1368, 1989.

44. BARDGETT R.D., SAGGAR S. Effects of heavy metal contamination on the short- term decomposition of labelled $\mathrm{C}$-glucose in a pasture soil. Soil Biol Biochem, 26, 727, 1994.

45. TSAI Y.L., OLSON B.H. Rapid method for direct extraction of DNA from soil and sediments. Applied Environmental Microbiology, 57, 1070, 1991.

46. JANSE I., BOK J., ZWART G. A simple remedy against artifactual double bands in denaturing gradient gel electrophoresis. Journal of Microbiological Methods 57, 279, 2004

47. LI M.Y., ZHOU G.H., XU X.L., LI C.B., ZHU W.Y. Changes of bacterial diversity and main flora in chilled pork during storage using PCR-DGGE. Food Microbiology, 23, 607, 2006.

48. ZHAO D.Y., MA T., ZENG J., YAN W.M., JIANG C.L., FENG J.W., XU Y.N., ZHAO H.Z. Phospholipid fatty acids analysis of the vertical distribution of microbial communities in eutrophic lake sediments. Int. J. Environ. Sci. Te. 8 (3), 571, 2011.

49. LEPC J., SMILAUER P. Multivariate analysis of ecological data using CANOCO. Cambridge University Press, Cambridge, 2003

50. SAPP M., WICHELS A., WILTSHIRE K.H. Bacterial community dynamics during the winter-spring transition in the North Sea. FEMS Microbiol. Ecol. 59 (3), 622, 2007.

51. TER BRAAK C.J.F. The analysis of vegetation-environment relationships by canonical correspondence analysis. Vegetation 69 (1), 69, 1987.

52. MICHAEL SCHULTZ RASMUSSEN, HENRIK BREUNING-MADSEN, CHRISTIAN CHRISTIANSEN Variations in the hydrostatic pressure may trigger estuarine full water column anoxia. Estuarine, Coastal and Shelf Science, 59, 21, 2004.

53. CHRISTIAN TAMBURINI, MADELEINE GOUTX, CATHERINE GUIGUE, MARC GAREL, DOMINIQUE LEFE'VRE Effects of hydrostatic pressure on microbial alteration of sinking fecal pellets [J]. Deep-Sea Research II, 56, 1533, 2009.

54. BARTLETT D.H. Pressure effects on in vivo microbial processes. Biochimica et Biophysica Acta, 1595, 367, 2002. 